\title{
玉米幼穗再生苗在试管分化裸露的雄雄幼穗
}

\author{
吴家道 \\ （安徽省农业科学院，合肥）
}

玉米是重要的粮食作物, 也是发展食品、畜牧业和工业的重要原料. 杂交玉米增产潜力 大,利用花约培养玉米纯合自交系已在我国首先取得成功,并开始应用于育种实践. 玉米的组 织培养, Green 等 ${ }^{[3,4]}$ 进行过幼肧、盾片培养获得再生植株。培养未成熟花序没有获得成功. 本 试验进行玉米幼穂组织培养, 以探索其利用的可能性和应用价值. 试验结果表明,玉米幼穗外 植体可诱导出大量的绿苗, 并且在试管中进行健壮培养, 绿苗再分化出裸露的雌雄幼穗, 为研 究禾本科植物的发育生理和器官分化提供了有益的素材,对玉米育种工作也有一定意义.

\section{一、材料和方 法}

材料用本院杂粮室配制的“肖纱 3-2 2330 ”玉米杂交种. 取田间生长植株的幼穗，长 10 毫米左右,以 $10 \%$ 双氧水消毒 10-15 分钟,切成 2-3 毫米切段接种在固体培养基上,一般每 管接种 2-3 块外植体. 诱导培养分暗培养和光培养 (自然光), 培养温度为 $30-32^{\circ} \mathrm{C}$, 分化培 养每天光照 10 小时, 强度为 2000 勒克斯, 健壮培养温度为 $25-27^{\circ} \mathrm{C}$, 每天光照也为 10 小时.

基本培养基均为 $\mathrm{N}_{6}$, 琼脂 $0.6 \%, \mathrm{pH} 5.8$. 诱导愈伤组织每升附加 2,4-D 2 毫克、 NAA 0.5 毫克或 2, 4-D 2 毫克、BA 3 毫克、KT 2 毫克、NAA 0.5 毫克; 分化培养每升附加 BA 2 毫克、 NAA0.5 毫克; 健壮培养每升附加 NAA0.5 毫克. 采用 Giemsa 染色法 ${ }^{[2]}$ 检查根尖细胞染色体数.

\section{二、结 果}

1. 从幼和外植体再生绿色小植林幼穗外植体接种在诱导培养基上,十天后幼穂顶部、 中部和基部切块的表面及切口处陆续产生大量愈伤组织 (图 1). 单用生长素时外植体膨大为 原体积的二倍, 三周后有 $10 \%$ 分化根。在加生长素和细胞分裂素的培养基上, 外植体稍有膨 大, 未发现根的分化. 暗培养比光培养的愈伤组织出现早、增殖快、体积大. 单用生长素 $\mathrm{N}_{6}$ 培 养基接种外植体 46 块, 全部产生愈伤组织, 愈伤组织诱导率为 $100 \%$; 用生长素和细胞分裂素 的接种外植体 48 块，有 38 块产生愈伤组织,愈伤组织诱导率为 $79.1 \%$.

15 天后, 当愈伤组织达到 2-3 毫米大小,即转移到分化培养基上,培养 5 天, 愈伤组织增 大, 并开始出现绿芽点, 很快形成绿芽丛 (图 2), 25 天后产生有根、茎、叶的完整小植株(图 3). 愈伤组织分化力较强,一般每块产生绿苗 4-11 株,最多的为 30 多株. 未发现白化苗和白、绿 嵌合体. 单用生长素诱导产生的愈伤组织, 转移 32 块进行分化培养, 有 6 块分化绿苗, 分化率 $18.7 \%$; 用生长素和细胞分裂素产生的愈伤组织转移 27 块, 有 21 块分化绿苗, 分化率 $77.7 \%$.

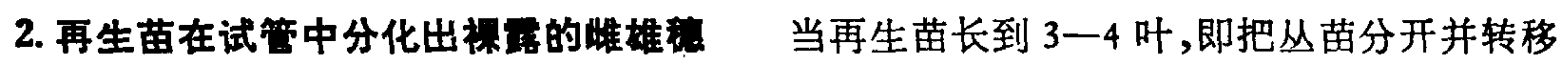
到健壮培养基上, 几天后栽人士壤中生长正常. 若把绿苗放在试管中继续培养, 10 天后出现一 种罕见的现象, 绿苗基部叶腋间和生长点分别分化出裸露的倠穗和雄穂 (图 4), 并迅速伸长. 20 天雌雄幼穂均进入小花分化初期 ${ }^{[1]}$. 此时雌穂长 10 毫米, 雌菀原始体排列整齐共 6 行, 每

本文1982 年3月19 日收到。 
行有㫿荡原始体 13 个; 雄穗长 12 毫米,主轴基部出现比较明显的雄穗分枝 2 个, 主轴上部形 成小稳原始体,下部可以看到筑片的形成,此时苗高 5-10 厘米,叶 5-6 片,根系发达.

20 天后，把分化裸露倠雄穂的绿苗转换到新鲜健壮培养基上，其雄穆基部叶原始体开始 伸长,并渐次包被雄䄼（图 5), 叶数 8 片(图 6), 倠穗苞叶原始体也有所伸长,可见小苞叶数 6 片(图 7), 这种植株检查根尖细胞染色体数为 20 条(图 8), 与正常二倍数一致.

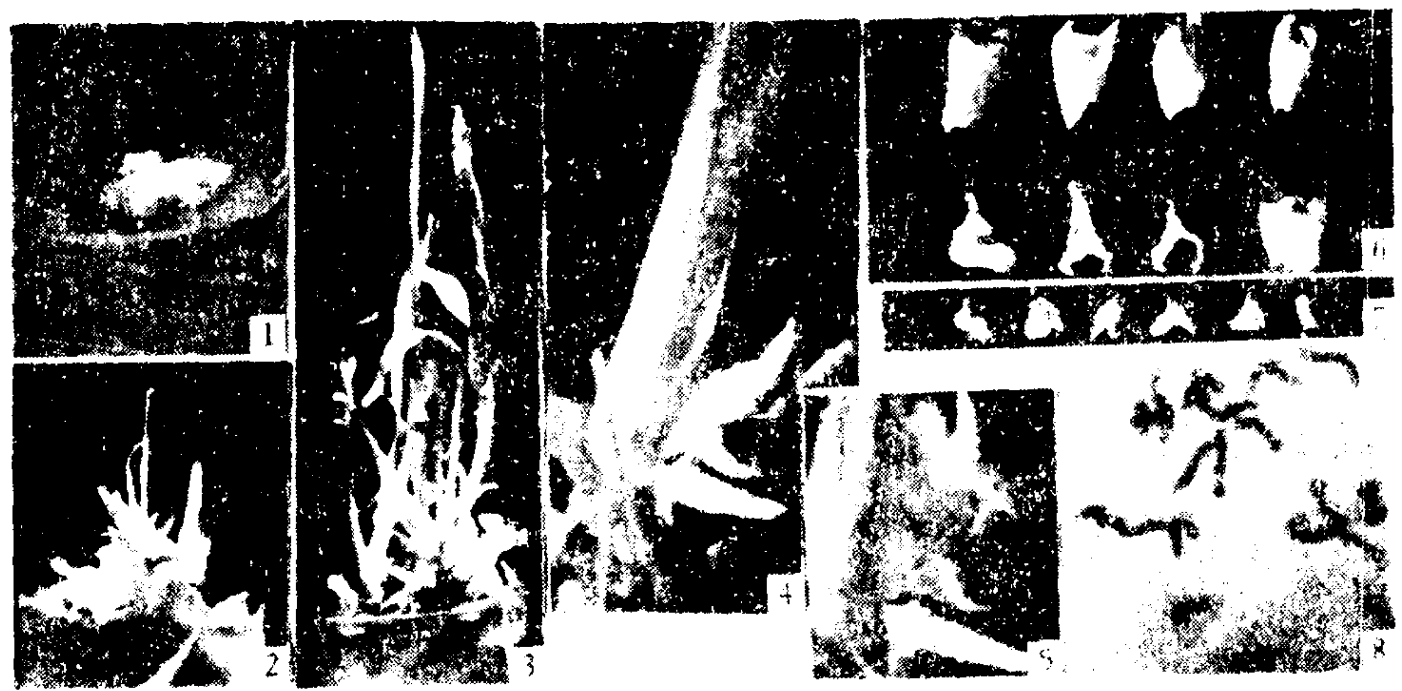

图 1-8

1. 幼稳形成的俞伤组织；2. 愈伤组织分化的绿芽丛；3.再生完整的小植株；4. 绿苗在健壮培养

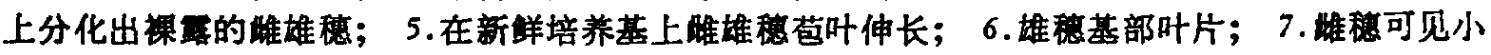
苍叶； 8. 根尖细胞染色体

\section{三、讨 论}

（1）本试验采用玉米幼穂组织培养获得了大量的再生完整植株, 这是玉米幼穂培养的首 次报道. 同时再生苗在试管中分化出裸露的倠雄穗, 这又是禾谷类作物组织培养中不可多得 的材料. 基于玉米幼穗培养方法简单，再生成苗率高. 我们可以利用这些材料在人工控制条 件下, 研究玉米的发育生理和器官分化. 同时有可能建立无性凡殖系以保持玉米杂种优势。

（2）众所周知,玉米在田间正常生长条件下,倠雄穂分化在苍叶内进行, 苍叶伸长先于㫿 雄穗. 而在试管中,幼穗分化和苍叶出生则与之相反,雌雄穗先行分化,并迅速伸长裸露, 叶和 苞叶原始体暂停发育,一旦把这种苗转移到新鲜培养基上, 倠雄穂苞叶原始体又开始发育, 并 逐渐伸长. 其根尖细胞染色体仍是正常二倍体数. 看来,玉米倠雄穂裸露现象的出现,属于遗 传型改变的可能性小,而培养基诱导的可能性大. 培养基在代谢过程中,有可能产生一种次生

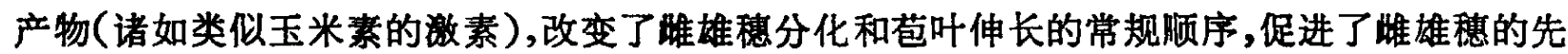
期启动,其机制需待进一步研究.

致谢: 安微农学院李展同志协助做染色体制片,特此致谢。

[1]《玉米遗传育种学》编写组,玉米遗传育种学, 1979, 20-25。

\section{考文淔}

[2] 陈瑞阳等,植物学报, 21 (1979),3: 297-298.

[3] Green, C. E., 第四届国际植物组织与细胞培兼讨论会文集(中译本)，1978.

[4] Green, C. E. ct al., Crop Sci., 15 (1975), 3: 417-421.

[5] Yamada, Y., Applied and Fundamental Aspects of Plant Cell, Tissue, and Organ Culture (Eds. Reinert, J. \& Bajaj, Y. P. S.), Springer Verlag, N. Y., 1977, 144-159. 